\title{
ESTABLISHMENT OF OVERSOWN WHITE CLOVER ON UNIMPROVED NORTH AUCKLAND CLAY HILL COUNTRY
}

\author{
G. J. GoOLD \\ Scientist, Department of Agriculture, Whangarei
}

T. E. Ludecke and J. N. Parle

Ruakura Agricultural Research Centre

\section{INTRODUCTION}

In North Auckland, as is the case in all other areas of $\mathrm{New}$ Zealand, the key to pasture improvement lies in the introduction of legumes. Almost invariably poor pasture production is associated with poor clover growth. Contributing factors to poor clover establishment and growth are low amounts of available phosphate, potassium, molybdenum and sulphur, acid soil conditions and ineffective nodulation. This paper is concerned with the germination and establishment of white clover on unimproved N orth Auckland clay hill country. White clover establishment has been investigated on the soils of two northern yellow-brown earth soil suites, namely, the Marua suite from greywacke parent material and the Waiotira suite, from massive sandstone. These soils have been described by Taylor and Sutherland ( 1953) and are shown in their order of leaching in Tables 1 and 5 , respectively.

\section{(1) Marua Suite}

\section{TRIALS AND RESULTS}

In the spring of 1966, lime by phosphate factorial trials was laid down on all four unimproved soils of the suite. The rates of lime were $0,10,20$, and 40 cwt per acre and the rates of phosphate were equivalent to $3,6,9$, and $12 \mathrm{cwt}$ of superphosphate per acre. Basal dressings of molybdenum, sulphur, and potash were applied to all trials, which were oversown with $3 \mathrm{lb}$ 'Grasslands Huia' white clover, $2 \mathrm{lb}$ Lotus major, $10 \mathrm{lb}$ 'Grasslands Ruanui' ryegrass and $5 \mathrm{lb}$ 'Grasslands A riki' ryegrass seed per acre. As it is not a general practice in Northland, the clover and lotus seed was not inoculated. 
CLOVER ESTABLISHMENT ON HILL COUNTRY

table 1: Details of the marua suite trial SITES

\begin{tabular}{|c|c|c|c|c|}
\hline District & Soil Type & $\begin{array}{l}\text { Soil } p) \\
(0-3 \text { i }\end{array}$ & n.) Topography & $\begin{array}{l}\text { Dominant } \\
\text { Vegetation }\end{array}$ \\
\hline Onerahi & Te Ranga clay loam & 4.9 & Very steep & $\begin{array}{l}\text { Burnt over manuka } \\
\text { scrub }\end{array}$ \\
\hline Onerahi & Marua clay loam & 5.1 & Hilly to steep & $\begin{array}{l}\text { Bracken and } \\
\text { unimproved } \\
\text { species }\end{array}$ \\
\hline Marua & Rangiora clay loam & 5.0 & Undulating & $\begin{array}{l}\text { Cultivated from } \\
\text { manuka scrub }\end{array}$ \\
\hline Whareora & Hukerenui silt loam & 5.1 & Undulating & $\begin{array}{l}\text { Cultivated from } \\
\text { manuka scrub }\end{array}$ \\
\hline
\end{tabular}

Details of the trial sites are given in Table 1.

Visual clover establishment and vigour pointings taken in January, 1967, showed that the responses to rates of phosphate at the Te Ranga soil site were not pronounced. On the more leached Marua soil, responses were marked up to the equivalent of 6 cwt of superphosphate per acre. On the weakly podzolized Rangiora and moderately podzolized Hukerenui soils, phosphate responses were recoraed up to the equivalent of 9 cwt superphosphate per acre. The results were statistically analysed using Duncan's Multiple Range test (Duncan, 1955). The results are summarized in Tables 2 and 3.

Responses to additions of lime occurred at the Te Ranga soil site in respect to percentage clover establishment, although the vigour of the clovers was not greatly influenced. No lime responses were recorded at the Marua soil site. An outstanding lime response was recorded at the Rangiora soil site although rates above $10 \mathrm{cwt}$ per acre were of no increased benefit. On the moderately podzolized Hukerenui soil, no lime responses occurred in the establishment phase and, provided the phosphate deficiency was corrected, there was good establishment of the oversown white clover seed.

The clover establishment failure at the Rangiora soil site in the absence of lime resulted in soil samples being taken for analysis of rhizobia numbers in the O-3 in. soil levels from the no-lime plots and the $40 \mathrm{cwt}$ lime plots. The results are shown in Table 4.

The figures suggest that the addition of $40 \mathrm{cwt}$ of lime at the Rangiora soil site has made conditions favourable for the multiplication of Rhizobium trifolii in the soil. At the Marua and Hukerenui soil sites, where no lime responses 
TABLE 2: EFFECT OF PHOSPHATE ON CLOVER ESTABLISHMENT

(Mean \% Establishment taken 20.1.67)

\begin{tabular}{|c|c|c|c|c|c|c|c|c|}
\hline \multicolumn{4}{|c|}{$\begin{array}{c}\text { Phosphate Rate } \\
(c w t / a c)\end{array}$} & & $\begin{array}{c}\text { Te Ranga } \\
40.8 \mathrm{abA}\end{array}$ & $\begin{array}{c}\begin{array}{c}\text { Soil } \\
\text { Marua }\end{array} \\
66.8 \mathrm{bB}\end{array}$ & $\begin{array}{c}\begin{array}{c}\text { Types } \\
\text { Rangiora }\end{array} \\
24.2 \mathrm{bA}\end{array}$ & $\frac{\text { Hukerenui }}{60.8 \text { bB }}$ \\
\hline $\begin{array}{r}3 \\
6 \\
9 \\
12\end{array}$ & 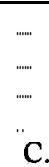 & ..."' & 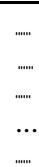 & 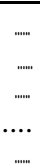 & $\begin{array}{l}40.8 \mathrm{abA} \\
50.6 \mathrm{aA} \\
49.1 \mathrm{aA} \\
35.7 \mathrm{bA} \\
14.0 \%\end{array}$ & $\begin{array}{c}66.8 \mathrm{bB} \\
76.8 \mathrm{aA} \\
75.0 \mathrm{aA} \\
76.2 \mathrm{aA} \\
6.4 \%\end{array}$ & $\begin{array}{l}24.2 \mathrm{bA} \\
34.4 \mathrm{abA} \\
48.7 \mathrm{aA} \\
47.0 \mathrm{aA} \\
24.4 \%\end{array}$ & $\begin{array}{l}60.8 \mathrm{bB} \\
68.8 \mathrm{aAB} \\
74.4 \mathrm{aA} \\
71.5 \mathrm{aAB} \\
7.2 \%\end{array}$ \\
\hline
\end{tabular}

TABLE 3: EFFECT OF LIME ON CLOVER ESTABLISHMENT

(Mean \% Establishment taken 20.1.67)

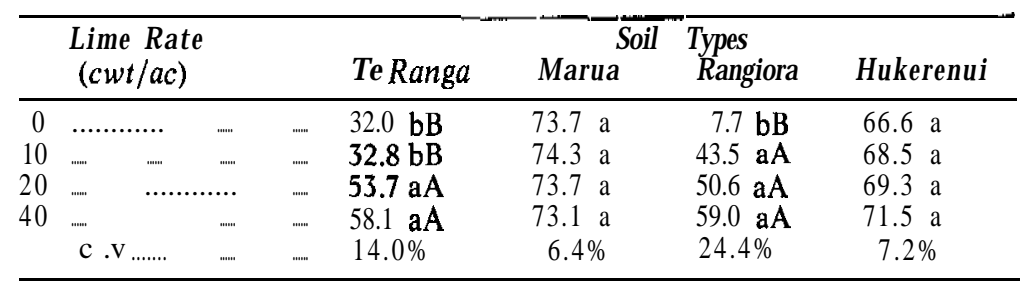

TABLE 4: RHIZOBIA NUMBERS IN SOILS OF MARUA SUITE (Per Gram Wet Soil)

\begin{tabular}{|c|c|c|c|c|c|c|c|c|}
\hline & & & & & & Marua & Rangiora & Hukerenui \\
\hline $\begin{array}{l}\text { No lime } \\
40 \text { cwt lime }\end{array}$ & ....... & $\ldots$ & $\cdots$ & . & $\ldots$ & $\begin{array}{l}10^{5} \\
10^{\prime}\end{array}$ & $\begin{array}{c}0 \\
10\end{array}$ & $\begin{array}{l}10^{5} \\
10^{z}\end{array}$ \\
\hline
\end{tabular}

TABLE 5: DETAILS OF WAIOTIRA SUITE TRIAL SITES

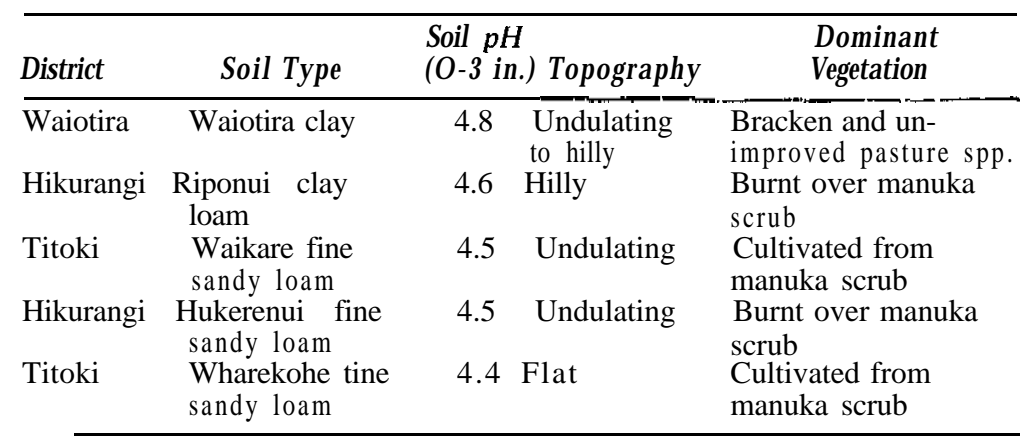


were recorded, there were adequate numbers of rhizobia present in the no-lime plots.

(2) Waiotira Suite

In the autumn of 1967, factorial trials were laid down on five unimproved soils of the Waiotira suite. The nutrients and rates examined on a presence and absence basis and in all combinations were : lime, 40 cwt per acre ; potassium chloride, 2 cwt per acre; sodium molybdate, 5 oz per acre; sulphur, $80 \mathrm{lb}$ per acre ; and copper sulphate, $5 \mathrm{lb}$ per acre. A basal dressing equivalent to 4 cwt of superphosphate per acre was applied to all trials which were oversown with a seed mixture similar to that used in the Marua suite studies. The clover seed was not inoculated. Details of the trial sites are shown in Table 5.

Visual clover establishment and vigour pointings taken two months after sowing at each trial site showed that these criteria had been profoundly influenced by the addition of lime at all sites, except the Waiotira clay (see Table 6). At the Waiotira clay site, molybdenum significantly (5\% level) improved the percentage clover establishment. Molybdenum did not interact with lime at the establishment phase of this trial. In the absence of lime on all other soils of the suite there was virtually no establishment of oversown uninoculated white clover seed. The dominance of the lime response on these trials was such that the influence of other nutrients was not clear. Although some nutrients had minor effects on clover establishment figures (particularly copper) they did not have any influence on the vigour of the plants and, except for molybdenum, may not be important in the establishment phase.

TABLE 6: CLOVER VIGOUR POINTINGS AND NUMBERS OF RHIZOBIA IN SOILS OF WAIOTIRA SUITE

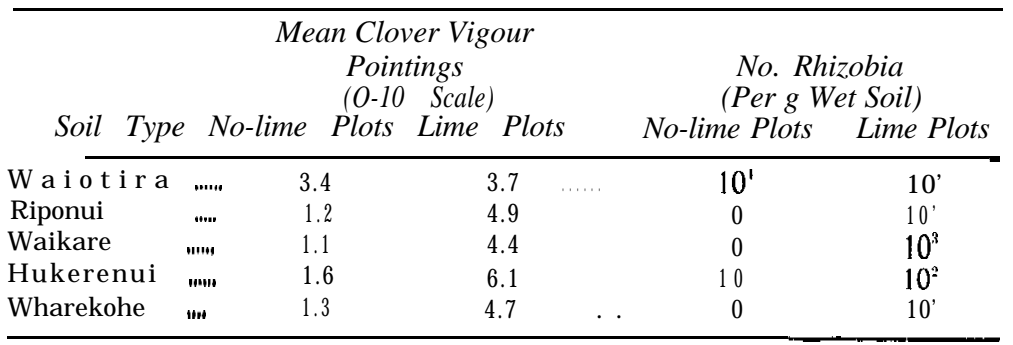


TABLE 7: PERCENTAGE NODULATION OF WHITE CLOVER PLANTS ON SOILS OF WAIOTIRA SUITE (Pointings taken 5.10.67)

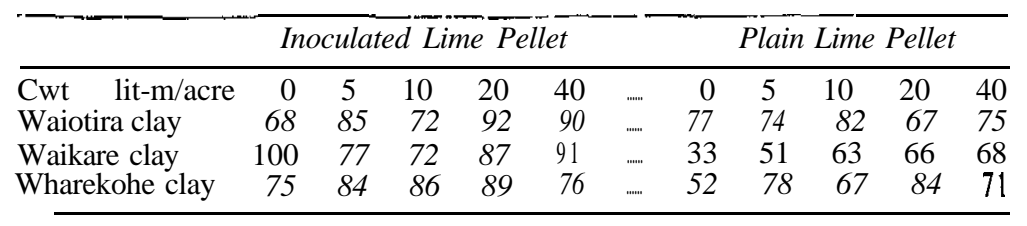

Soil samples of 0 to 3 in. from the no-lime and $40 \mathrm{cwt}$ lime plots were taken in September, 1967, and the rhizobia numbers determined for the soils of the Waiotira suite. The results are shown in Table 6.

At all soil sites, except the Waiotira clay loam, the numbers of rhizobia present in the no-lime plots are considered to be inadequate for satisfactory nodulation of white clover seed. The addition of lime to these soils has resulted in a marked build-up of the rhizobia numbers and hence marked nodulation responses in clover establishment.

To determine the effect of rates of lime in the presence of inoculation, factorial trials were laid down at the Waiotira, Waikare and Wharekohe soil sites in August, 1967. The treatments were lime pelleted, uninoculated white clover and lime pelleted inoculated white clover by $0,5,10$, 20 , and 40 cwt lime per acre. Basal molybdic superphosphate at 5 cwt per acre was applied to all plots. The single seed technique of Cullen (1965) was used in these trials, 50 seeds being sown in each plot. After the fertilizer and lime treatments were applied, undisturbed soil cores from all plots were placed in tins and taken to Auckland for an identical study under controlled glasshouse conditions by $\operatorname{Dr} D$. Dye and A. Hastings of Plant Diseases Division, D.S.I.R. The results from establishment pointings taken two months after sowing are shown in Table 7. Clover plants were rated on a 0 to 4 scale and plants with a vigour rating of three or four are considered to have successfully nodulated. The number of these plants per treatment has been expressed as a percentage of the total plants which germinated.

The results have shown that clover can be established successfully at the Waikare and Wharekohe soil sites if the clover seed is adequately inoculated in the presence of nil or very low rates of lime. Without inoculation, medium to high rates of lime are needed to produce similar establishment results. There was no inoculation response at the 
Waiotira soil site confirming the belief that there were adequate numbers of rhizobia present already in the soil. The glasshouse studies have produced marked inoculation responses on the Waikare and Wharekohe soils, and confirm the field findings that inoculation can replace the need for medium to high rates of lime on such soils for the initial establishment of white clover seedlings.

\section{DISCUSSION}

These studies of the factors influencing clover establishment on unimproved North Auckland clay hill country have shown that ineffective nodulation may be a widespread problem. Greenwood ( 1961) has previously shown that native soil rhizobia populations can be extremely low in an unimproved Wharekohe silt loam soil derived from mudstone and claystone. N odulation problems are inevitable on such soils unless the rhizobia populations are increased in the immediate vicinity of the germinating seedling and all nutrient deficiencies are corrected.

Phosphate deficiencies in the northern yellow-brown earths is widespread and acute (Lambert, 1961; Jackman, 1961; Walker and Adams, 1959; and Wells and Saunders, 1960). From the Marua soil suite studies, it would seem that rates of phosphate in the order of up to 6 cwt per acre are desirable for white clover establishment on the hilly to rolling hill soils and upwards of 9 cwt on the flatter, more leached soils.

A need for molybdenum on the northern yellow-brown earths has been predicted by Grigg (1960) although trial evidence has not been conclusive for all soils. On the soil type which produced no response to lime application (Waiotira clay loam), molybdenum significantly ( $5 \%$ level) improved clover establishment and vigour. On other soil types, the dominance of the lime effect was such that other nutrient responses could well have been masked.

The influence of lime at these trial sites was to improve the soil environment to such an extent that a-rapid build-up in rhizobia numbers occurred. Good inoculation and pelleting of clover seed provides for a high population of viable Rhizobium trifolii in the close proximity of the germinating seedlings, and trial results have confirmed that such a seed treatment replaces the need for moderate to high rates of lime on the soils of the Waiotira suite. The conflicting results obtained in Northland and other parts of $\mathrm{New}$ Zealand in recent seasons to' the establishment of inoculated clover seed has been attributed to the use of Rhizobium 
trifolii cultures with extremely low viability (J. N. Parle, pers. comm.).

It is stressed that in this paper the role of lime in the successful establishment of white clover has been investigated only. Lime may be needed for high sustained production of pastures. These aspects are being investigated in further trials.

\section{CONCLUSIONS}

The series of trials discussed in this paper have resulted in the following conclusions for the establishment of oversown white clover on unimproved North Auckland clay hill soils :

(1) Medium to high rates of phosphate are needed.

(2) High rates of lime are not required provided the seed is inoculated with proven viable cultures of Rhizobium trifolii.

(3) In addition to inoculation, lime at low rates should be applied on the medium and strongly podzolized soils.

It is considered that these findings could be of considerable economic importance in the improvement of $\mathrm{N}$ orth Auckland clay hill country.

\section{ACK N O W LEDGEMENTS}

The authors would like to thank W. B. McMeikan, E. N. Honore, B. Hunt, N. J. Kimpton, and others, for assistance in sowing and recording trials; Dr D. Dye and A. Hastings for the preparation of seed treatments and glasshouse studies; and J. E. Cox of D.S.I.R. Soil Bureau for the typing of the various soils.

\section{REFERENCES}

Cullen, N. A. 1965: N.Z. I. agric. Sci., 1: 25-7.

Duncan, D. B. 1955: Biometrics 11: 1-42.

Greenwood, R. M. 1961: N.Z. I. agric. Res., 4: 275-89.

Grigg, J. L. 1960: Ibid 3: 69-86.

Jackman, R. H. 1961: Ibid 4: 361-74.

Lambert, J. P. 1961: Ibid 4: 348-60.

Taylor, N. H.; Sutherland, C. F. 1953: Proc. 15th Conf. N.Z. Grassl. Ass., 25-38.

Wells, N.; Saunders, W.M.H. 1960: N.Z. J. agric. Res., 3: 279-99.

Walker, T. W.; Adams, A. F. R. 1959: Soil Sci., 87: 1-10. 


\section{DISCUSSION}

Would one of the speakers elaborate on the failure of Rhizobium trifolii inoculants used in the past?

J. N. PAKLE: From evidence all over the country it appeared that strains being used were not very effective. Plant Diseases Division work showed that these strains had a short viability. Present inoculum can be safely used.

In the past in Northlund, clover has struck on poor soil, but wet conditions have caused problems. Was this the case in the trials?

G. J. GooLd: In this series of trials, clover made excellent growth through both winters.

T. E. LudEcKe: It is possible that the clover plants concerned did not nodulate.

Have peat inoculants come up to expectations?

DR PARLE: WC have had trouble with peat inoculum, but at present WC have no hesitation in using certified inoculants.

There seems to be a luck of clovers in Northland at present. Is this usual? Is inoculum profitable in later development?

Mr Goold: Clover vigour is a problem because of grasses like paspalum and kikuyu which grow vigorously when clover is making its main growth. As the cost is low, I would recommend inoculating clovers in all situations.

COMMEnt (J. P. LAMRERT): With paspalum and kikuyu well managed, good clover vigour results. Lack of clover at present is due to lack of moisture.

Comment (DR R. W. Brougham) : 1 would suggest that the present lack of clover growth may be due to preferential grazing keeping clover content of pastures low.

How widely distributed was the problem of second rate inoculum?

Mr LudECKE: A New Zealand-wide problem. At Wanaka in 1964-5, 40\% of plants nodulated; in the following ycar, on the same soil, only $2 \%$ nodulated. Plant Diseases Division pinpointed the problem as being low viability. All clover seeds used in mixtures should be inoculated. 